\title{
Variation in Thermal Time Model Parameters between Two Contrasting Chickpea (Cicer arietinum) Cultivars
}

\author{
Atif Hassan Naim1, Faisal El Gasim Ahmed ${ }^{2}$ \\ ${ }^{1}$ Faculty of Agricultural and Environmental Sciences, University of Gadarif, Gadarif, Sudan \\ ${ }^{2}$ Faculty of Agriculture, University of Khartoum, Shambat, Sudan \\ Email: atif882002@yahoo.com,fgahmed2005@yahoo.com
}

Received 3 November 2015; accepted 5 December 2015; published 10 December 2015

Copyright (C) 2015 by authors and Scientific Research Publishing Inc.

This work is licensed under the Creative Commons Attribution International License (CC BY). http://creativecommons.org/licenses/by/4.0/

c) (i) Open Access

\begin{abstract}
A laboratory experiment was carried out to determine the effect of temperature on germination and early seedling establishment and to study the variation among thermal time model parameters for two contrasting chickpea cultivars. Seeds were subjected to six constant temperatures from $10^{\circ} \mathrm{C}$ to $35^{\circ} \mathrm{C}$. A complete randomized design was used with four replications. Analysis of variance showed significant differences $(p<0.05)$ among all characters studied. The final germination percentage of both cultivars significantly $(p<0.05)$ increased with increasing temperature up to $25^{\circ} \mathrm{C}$, and thereafter there was a sharp decrease in final germination at super optimal temperatures $\left(30^{\circ} \mathrm{C}\right.$ and $35^{\circ} \mathrm{C}$ ). Desi type cultivar (small seeded) locally called "Jabel Marra" significantly (p $<0.05$ ) exhibited higher final germination percentage and germination rate compared with the smaller seeded kabui type cultivar "Shendi" at all temperatures. The median $\left(\theta_{T(50)}\right)$ of the thermal time was significantly $(p<0.05)$ different between the two chickpea cultivars. The large seeded cultivars (Shendi) recorded significantly $(p<0.01)$ higher median thermal time than the small seeded cultivars (Jabel Marra). The results also revealed significant $(p<0.01)$ differences between the two cultivars on the other parameters of thermal time model. On the other hand, the small seeded cultivar (Jabel Marra) scored lower total dry matter and temperature tolerance index (TTI) compared with the large seeded cultivar (Shendi) at all temperatures studied.
\end{abstract}

\section{Keywords}

Chickpea, Cicer arietinum, Germination, Thermal Time

\section{Introduction}

Chickpea (Cicer arietinum L.) is the third most extensively planted grain legume in the world after dry bean and 
field pea [1]. Besides being an important legume crop for human nutrition, chickpea also plays an important role in increasing and maintaining soil fertility and the recovery of marginal lands, especially in arid and semi-arid regions [1]. Chickpea is currently grown on about 12 million hectares worldwide with an average annual production of 10.9 million tons [2]. About $95 \%$ of chickpea cultivation and consumption is in the developing countries [3]. In Sudan, chickpea is traditionally grown as a winter crop in the northern part, however, its production has expanded recently to the central clay plain of central Sudan [4]. The growing season is restricted to a short period of time by the high temperatures prevailing at the beginning and at the end of the season [4]. The chickpea yields in Sudan vary from 0.83 to $2.8 \mathrm{t} / \mathrm{ha}$, depending on weather conditions [5]. Temperature is one of the most chickpea production constraints in the main production areas in Sudan. Worldwide, chickpea is either grown during the post rainy season on stored soil moisture (South Asia and spring sown Mediterranean) or as a Mediterranean winter crop in season rainfall; in both instances the crop is exposed to terminal drought which is accompanied by rising temperatures. The South Asian crop may also experience high temperatures in the seedling phase if planted early [6]. Chickpea productivity is constrained by several abiotic stresses [7] [8] and temperature is one of the most important determinants of seed germination and seedling growth over a range of environments and may limit chickpea yield [9]. Cultivars grown in Sudan are either local (desi) type (called "Jabel Marra”) characterized by smaller, angular, light brown (pigmented) seeds and early mature or introduced Mediterranean (kabuli) type with larger, rounded seeds which lack pigmentation which is late mature cultivar such as NEC 2491 (locally called “Shendi”). The second cultivar has been released and recommended to be grown in Northern Sudan due to their vigorous growth and high yield potentiality [4]. Since kabuli-types are indigenous to Mediterranean areas, we presume that some genotypes may have a degree of adaptation to low temperature. Genotypic variability amongst the desi and kabuli cultivars in Sudan has been reported recently [4].

The establishment of plants is often limited by temperature when moisture conditions are favourable [10]. Germination characteristics have often been used for evaluating response of plant development to temperature. Many researchers [11]-[13] found a linear relationship between the inverse time of germination (germination rate) and temperature. Temperature is the single most important factor governing the germination [14]. Previous studies have shown that germination rate usually increases linearly with temperature, at least within a well-defined range and declines sharply in higher temperatures [14] [15]. This temperature range has been defined as cardinal temperatures, i.e., a minimum or base temperature $\left(T_{b}\right)$, maximum temperature $\left(T_{c}\right)$ that germination rate at above of that will be zero and optimum temperature $\left(T_{o}\right)$ at which the germination rate is the highest [15]. Several researchers have shown that the cardinal temperatures for germination depend on species and within species vary significantly [16]. At suboptimal temperatures the thermal time approach can be used to predict germination time. Thermal time (degree-day or hour) principle was first introduced by [13] to describe the linear relationship between germination rate and constant temperature in pearl millet.

Seed size is a genotypic character which varies between and within species. It has been well known that larger or heavier seeds usually germinate faster than smaller or lighter seeds of the same species [17]. Because thermal time model is based on germination rate, we presume that thermal model parameters may differ for two contrasting chickpea cultivars varying in their seed size.

The objectives of this study were to test the assumption of the thermal model using two contrasting chickpea cultivars and to determine the effect of thermal requirement on germination and early growth of this crop.

\section{Material and Methods}

Two chickpea cultivars were obtained from the Agricultural Research Corporation (ARC) in Sudan, namely; Shendi (kabuli-type) and Jabel Marra (desi-type). Shendi cultivar; large seeded cultivar is described as a late mature and small seeded variety and the other cultivar (Jabel Marra); small seeded cultivar is described as an early mature variety. Germination tests of fresh mature seeds were carried out by putting seeds in Petri dishes with two layers of moistened filter papers (Whatman, No.1). The Petri dishes were randomly put in six incubators (Sanyo Versatile Environmental Chamber MLR-350 H), six temperatures from $10^{\circ} \mathrm{C}$ to $35^{\circ} \mathrm{C}$, at $5^{\circ} \mathrm{C}$ interval, were randomly assigned to each incubator. The relative humidity inside the incubator was $32 \%$ and the photoperiod is $12 \mathrm{hr}$ with $30 \mu \mathrm{mol}$ photons. $\mathrm{m}^{-2} \cdot \mathrm{s}^{-1}, 400-700 \mathrm{~nm}$. A randomized complete design (RCBD) was used with four replicates of 25 seeds each, at 7-day interval between replicates in each incubator. Clear plastic bags were used to seal Petri dishes to reduce water evaporation. Seeds were considered germinated when 2 mm of radicle was visible [18]. 
Final (cumulative) germination percentages were transformed using $\log _{10}$ Probit [18] [19]. Probit transformation linearizes the cumulative normal distribution, which facilitates modeling efforts [18] [20]. For modeling purposes a seed population was considered to be composed of subpopulations based on relative germination rate [18] [21]. The Probit procedure in SPSS, version (15) was used to estimate germination time or the $10 \%, 20 \%$, $30 \%, 40 \%, 50 \%, 60 \%, 70 \%$ and $80 \%$ subpopulations. Pearson Chi square test was used as the goodness-of-fit test $(\mathrm{p} \geq 0.10)$. The base temperature (the minimum temperature at which germination could occur) is generally assumed to be constant for a specific species. The base temperature $\left(T_{b}\right)$ was determined by plotting germination percentage (on a probit scale) against log-thermal time $\left(\log 10\left(T-T_{b}\right) t_{g}\right.$ ), where $T_{b}$ is unknown and estimated by changing the value of $T_{b}$ until the minimum residual variation is obtained [22]. On a plot of probit (germination) against log (thermal time), the median thermal time required for seed of the population corresponds to the thermal time when probit (germination) $=5$. The inverse of the slope of the fitted line is the standard deviation of the population responses to thermal time (i.e. the flatter the slope of the fitted line, the greater variation in response to thermal time between individual seeds).

$$
\operatorname{Probit}(g)=\left[\log \left(T-T_{b}\right) t_{g}-\theta_{T(50)}\right] / \sigma_{\theta T} \quad[18]
$$

where $T_{b} \equiv$ base temperature, $\theta_{T(50)} \equiv$ median thermal time, and $\sigma_{\theta T} \equiv$ standard deviation for thermal time.

These parameters were estimated for each seed size class of each cultivar for the construction of the thermal time model. General linear model (GLM) in SPSS was used to test differences in base temperature $\left(T_{b}\right)$ between subpopulations and the effects of genotype and seed classes on thermal model parameters $\left(T_{b}, \theta_{T(50)}\right.$ and $\left.\sigma_{\theta T}\right)$. Mean were separated with Fisher's protected least significant difference (FPLSD). Accuracy of thermal time model was measured by coefficient of determination $\left(R^{2}\right) . R^{2}$ was calculated as: 1-(SS residual/SS total), where, SS residual represents residual sum of squares and SS total is the total sum of squares, while SS residual = observed value - predicted value and SS total = observed value - mean. Germination rate index (GRI) which is independent on thermal time model, is calculated as:

$$
G R I=\left(G_{t o t} / P\right) * \sum\left(g_{i} / t_{i}\right)
$$

where $G_{\text {tot }}$ is the total number of germinated seeds in a dish at the end of the germination test; $P$ is the total number of seeds incubated; $g_{i}$ is the number of germinated seeds accumulated between time (d) $t_{i-1}$ and $t_{i}$. The effect of cultivars on GRI was also analyzed using general linear model (GLM) in SPSS (version 16).

Temperature tolerance index (TTI) was calculated as total plant (shoot + root) dry weight at different temperatures compared to the total plant dry weight obtained at optimum temperature as indicate below:

$$
T T I=\left(T D W \text { at } T_{x} / T D W \text { at } T_{i}\right) \times 100 \quad \text { [23] }
$$

where $T D W=$ total dry weight; $T_{i}=$ control treatment (at optimum temperature); $T_{x}=\mathrm{x}$ treatment (at corresponding temperature).

Statistical Analysis:

Hundred Seeds of each cultivar were put in incubators at six different temperatures and arranged in a complete randomized design (CRD) with four replicates. If there was a significant difference at $p<0.05$, the means separation was done for different treatments using least significant (LSD) method. To validate the thermal time model, correlation test was done and accordingly, the coefficient of determination $\left(R^{2}\right)$ and level of significance (P) were calculated. All statistical tests were done using a statistical package (SPSS version 16). Figures were constructed by using the computer software (Excel).

\section{Results}

The final germination percentage significantly increased with increasing temperature up to $25^{\circ} \mathrm{C}$, and thereafter there was a sharp decrease in final germination at $30^{\circ} \mathrm{C}$ and $35^{\circ} \mathrm{C}$ (Figure 1). The cultivar Jabel Marra (small seeded type) significantly recorded higher germination percentage than Shendi cultivar (large seeded type) at all temperatures (Figure 1).

Germination rate $\left(d^{-1}\right)$ of subpopulations, $G R(g)$, calculated from the predicted germination time course correlated strongly $\left(\mathrm{R}^{2}=0.92, \mathrm{P}<0.01\right.$ ) with temperature at the suboptimal range $10^{\circ}$ to $25^{\circ} \mathrm{C}$ (Figure 2). Base 
temperature was in the range between $1^{\circ}$ to $3^{\circ} \mathrm{C}$, and significantly differed between the two cultivars according to their seed size (Figure 2) the large seeded cultivar (Jabel Marra) obtained higher germination rate at all suppopulation and different temperatures (Figure 2(b)) compared with other cultivar (small seeded cultivar "Shensi") (Figure 2(a)). Table 1 showed that the mean $T_{b}$ for cultivar Shendi $\left(1.2^{\circ} \mathrm{C}\right)$ was about $1.8^{\circ} \mathrm{C}$ lower than that of Jabel Marra $\left(3.0^{\circ} \mathrm{C}\right)$. Also, there were significant differences in $\theta_{T(50)}$ and $\sigma_{\theta T}$ between the two cultivars (Table 1). The small seeded cultivars (Jabel Marra) scored higher thermal requirements compared with the large seeded cultivars.

Germination rate index was significantly different between the two cultivars due to the difference in their seed sizes at various temperatures (Figure 2)., and GRI was dependent on incubation temperature (Figure 3). The large seeds germinate faster than small seeds for both cultivars ( $\mathrm{p}<0.05)$, and cultivar "Jabel Marra" (Arman or kabuli type) germinated faster than the other cultivar "Shendi" (Pirooz or desi type) (Figure 3).

The mean total dry weight was significantly different between the two cultivars at different temperatures (Table 2). The cultivar (Shendi) obtained higher shoot and root dry weight than the other cultivar Jabel Marra. Increasing temperature significantly increased the total dry weight from $10^{\circ}$ to $25^{\circ} \mathrm{C}$, but at $30^{\circ}$ and $35^{\circ} \mathrm{C}$, the dry matter was decreased significantly for both cultivars. The TTI was followed the same trend as total dry weight, and revealed that at $10^{\circ} \mathrm{C}$, the effect of low temperature was very pronounced in dry matter, only there were $75 \%$ - 70\% decrease in dry matter compared with that at optimum temperature (Table 2). However, cultivar Jabel Marra scored lower dry matter and TTI compared to the other cultivar Shendi at all temperature studied (Table 2).

\section{Discussion}

It has long been known that seeds can germinate over a wide range of temperatures, but maximum germination and rate of germination typically reduce at the extremes of the range [24]-[26]. Recently, [27] have developed

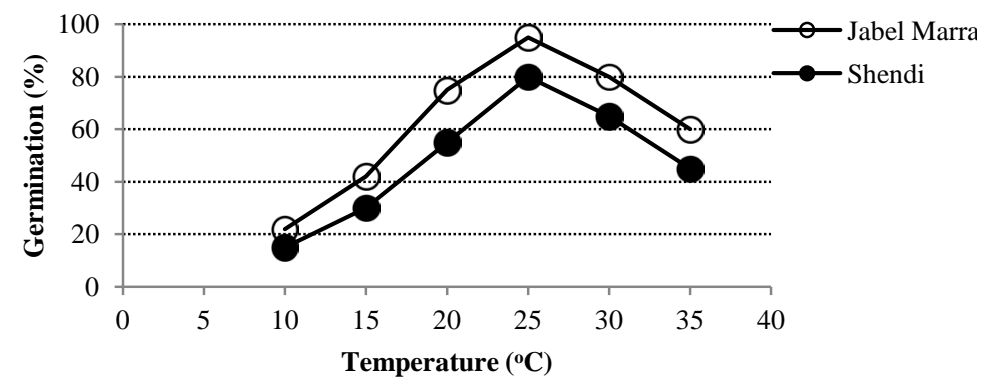

Figure 1. The effect of constant temperatures on the final seed germination percentage of two chickpea cultivars. Each data point represents a mean of four replicates of 25 seeds each.
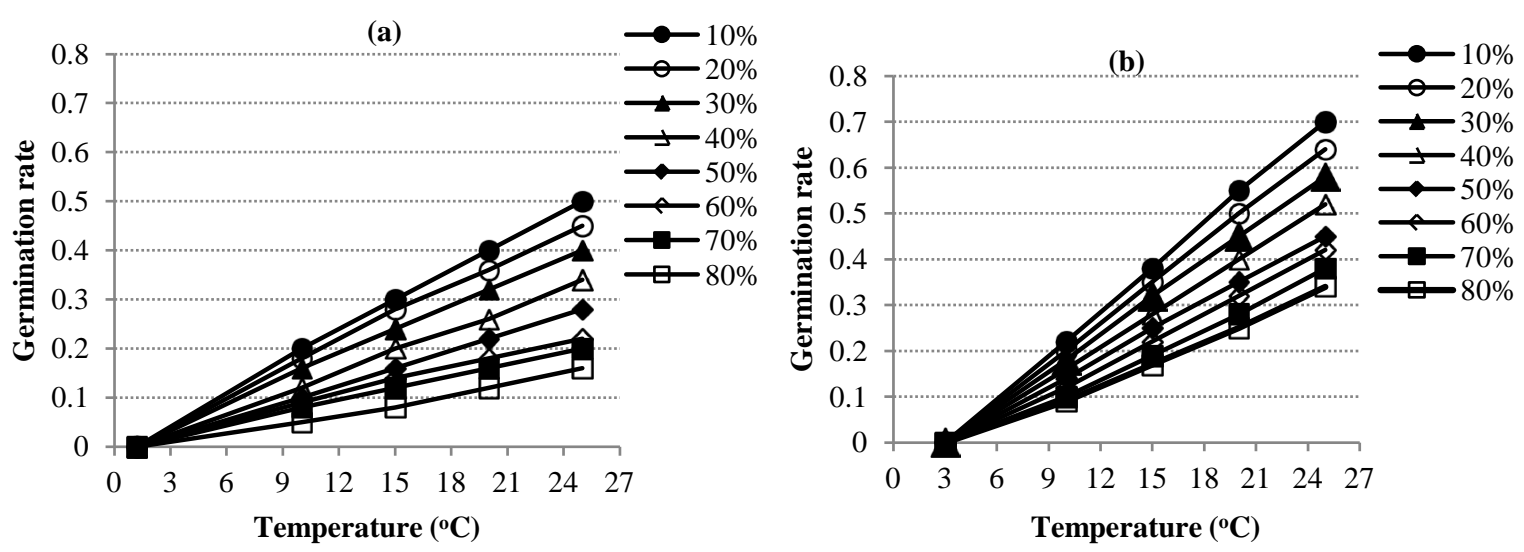

Figure 2. Germination rate $\left(d^{-1}\right)$ within the range of suboptimal temperatures as function of temperature and germination percentage or subpopulation $(10 \%, 20 \%, 30 \%, \ldots .$. etc) in two chickpea cultivars (a) Shendi and (b) Jabel Marra. The base temperature point was manipulated according to each germination subpopulation line. 
Table 1. Parameter estimates in thermal time equation to fit germination progress curves of two chickpea cultivars in water at suboptimum temperatures $\left(10^{\circ}, 15^{\circ}, 20^{\circ} \mathrm{C}\right)$ and optimum temperature $\left(25^{\circ} \mathrm{C}\right)$.

\begin{tabular}{|c|c|c|c|c|c|}
\hline \multirow[t]{2}{*}{ Cultivar } & \multicolumn{3}{|c|}{ Parameters of Thermal Time Model } & \multirow[b]{2}{*}{$* \mathrm{R}^{2}$} & \multirow[b]{2}{*}{${ }^{* *}$ p-value } \\
\hline & $\begin{array}{l}\text { Base Temperature in Water } \\
\qquad\left(T_{b(0)},{ }^{\circ} \mathrm{C}\right)\end{array}$ & $\begin{array}{l}\text { Median Thermal Time } \\
\quad\left(\theta_{T(50)},{ }^{\circ} \mathrm{Cd}\right)\end{array}$ & $\begin{array}{l}\text { Standard Deviation of Thermal Time } \\
\qquad\left(\sigma_{\theta \mathrm{T}},{ }^{\circ} \mathrm{Cd}\right)\end{array}$ & & \\
\hline $\begin{array}{c}\text { Shendi } \\
\text { (large seedsd type) }\end{array}$ & $1.2 \mathrm{a}$ & 117.5 a & $0.83 \mathrm{~b}$ & 0.87 & $<0.01$ \\
\hline $\begin{array}{c}\text { Jabel Marra } \\
\text { (small seeded type) }\end{array}$ & $3.0 \mathrm{~b}$ & $102.2 \mathrm{~b}$ & $1.70 \mathrm{a}$ & 0.97 & $<0.01$ \\
\hline$* * * \operatorname{LSD}_{(0.05)}$ & 0.56 & 8.5 & 0.7 & & \\
\hline
\end{tabular}

$T_{b(0)}$ : base temperature, $\theta_{T(50)}$ : median thermal time, $\sigma_{\theta T}$ : Standard deviation of thermal time. ${ }^{*} \mathrm{R}^{2}$ : Coefficient of determination; $* * \mathrm{p}-\mathrm{value:}$ level of significance.

Table 2. The mean total (shoot and root) dry weight (TDW) and temperature tolerance index (TTI) in two chickpea cultivars grown at different temperatures.

\begin{tabular}{|c|c|c|c|c|c|c|c|c|c|c|c|}
\hline \multicolumn{6}{|c|}{ TDW (g) } & \multicolumn{6}{|c|}{ TTI (\%) } \\
\hline $10^{\circ} \mathrm{C}$ & $15^{\circ} \mathrm{C}$ & $20^{\circ} \mathrm{C}$ & $25^{\circ} \mathrm{C}$ & $30^{\circ} \mathrm{C}$ & $35^{\circ} \mathrm{C}$ & $10^{\circ} \mathrm{C}$ & $15^{\circ} \mathrm{C}$ & $20^{\circ} \mathrm{C}$ & $25^{\circ} \mathrm{C}$ & $30^{\circ} \mathrm{C}$ & $35^{\circ} \mathrm{C}$ \\
\hline 0.75 & 1.17 & 2.31 & 2.48 & 2.05 & 1.80 & 30.24 & 87.5 & 93.14 & 100 & 82.66 & 72.58 \\
\hline 0.41 & 1.00 & 1.70 & 1.90 & 1.68 & 1.31 & 21.58 & 84.21 & 89.47 & 100 & 88.42 & 68.95 \\
\hline
\end{tabular}

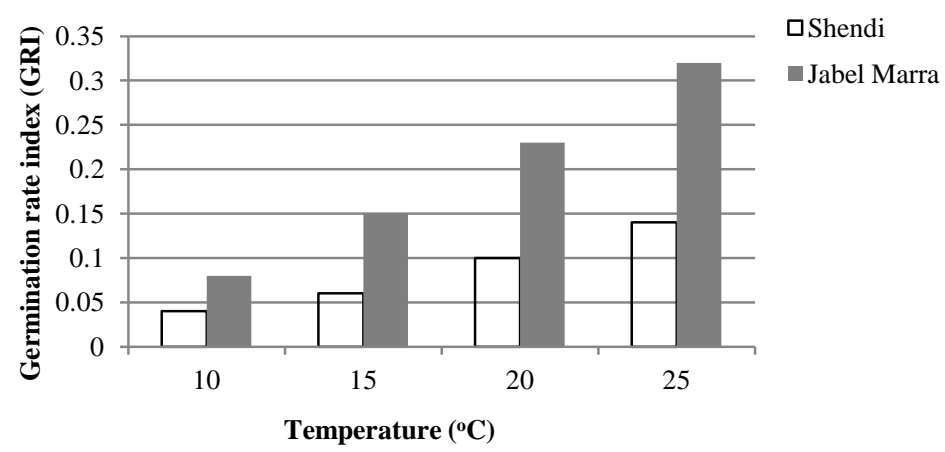

Figure 3. Germination rate index (GRI) of two chickpea cultivars seeds: Shendi, Jabel Marra, incubated at temperatures from $10^{\circ}$ to $25^{\circ} \mathrm{C}$. Bars indicate standard deviations.

and modified the thermal time model (which first proposed by [13]) to corporate suboptimal and super optimal temperatures. This study was conducted to assess the effect of genotypes and seed size on thermal requirement for germination. Our results revealed that although there were considerable difference between the two cultivars in all germination parameters, the thermal time requirement for $50 \%$ germination $\left(\theta_{T(50)}\right)$ and standard deviation of thermal time $\left(\sigma_{\theta T}\right)$ were also significant $(\mathrm{p}<0.05)$ between the two cultivars. On the other hand, the base temperature was significantly lower in large seeded cultivars (Shendi) than that of small seeded cultivars (Jabel Marra), allowing large seeds to accumulate more thermal time units than small seeds at the same temperature and subsequently to germinate faster. Our results were in accord with [18] but did not agree with the assumption that base temperature had little variation among genotypes of the same species [12] [27] [28]. The reason that $T_{b}$ was often considered as a constant may be for the ease of modeling [29]. Similar to this experiment, [30] reported that base temperature in the thermal time did not appear stable for wild species due to distinct genetic variability within the population. The variation in base temperature between seed size classes of chickpea may favor large seeds, allowing rapid germination and establishment. Poor emergence at low temperature is sometimes attributed to low seed quality, genotypes, disease resistance, and high thermal requirement [30]. According to the results of this study we recommend to introduce kabuli-types (the cultivar "Shendi") in Northern Sudan, and sowing should be done in the early winter (September-October) when temperature is around $20^{\circ} \mathrm{C}-25^{\circ} \mathrm{C}$ to 
guarantee uniform and rapid germination and a good seedling establishment.

\section{Acknowledgements}

The authors are grateful for funding received from Prof. Mustafa Salih, University of King Saud.

\section{References}

[1] Naim, A.H. and Ahmed, F.E. (2015) Interactive Effect of Temperature and Water Stress Induced by Polyethylene Glycol (PEG) on Germination and Recovery of Two Chickpea (Cicer arietinum L.) Cultivars. Open Access Library Journal, 2, e2005. http://dx.doi.org/10.4236/oalib.1102005

[2] FAO (2010) Food and Agricultural Organization Statistical Database. Food and Agricultural Organization, Rome. www.faostat.org

[3] Kassie, M., Shiferaw, B., Asfaw, S., Abate, T., Muricho, G., Ferede, S., Eshete, M. and Assefa, K. (2009) Current Situation and Future Outlooks of the Chickpea Sub-Sector in Ethiopia. EIAR (Ethiopian Institute of Agricultural Research) and ICRISAT (International Crops Research Institute for the Semi-Arid), India.

[4] Mohamed, A.A., Tahir, I.S.A. and Elhashimi, A.M.A. (2015) Assessment of Genetic Variability and Yield Stability in Chickpea (Cicer arietinum L.) Cultivars in River Nile State, Sudan. Journal of Plant Breeding and Crop Sciences, 7, 219-225. http://dx.doi.org/10.5897/JPBCS2015.0523

[5] Ahmed, A.T. (1996) Food Legumes Production situation. In: Salih, S.H., Ageeb, O.A., Saxena, M.C. and Solh, M.B., Eds., Production and Improvement of Cool-Season Food Legumes in the Sudan, Proceedings of the National Research Review Workshop, 27-30 August 1995, Wad Medani; ICARDA/Agricultural Research Corporation, Aleppo, 7-14.

[6] Berger, J.D. and Turner, N.C. (2007) The Ecology of Chickpea. In: Yadav, S.S., Redden, R.J., Chen, W. and Sharma, B., Eds., Chickpea Breeding and Management, CABI, Wallingford, UK, 657. http://dx.doi.org/10.1079/9781845932138.003

[7] Singh, K.B., Malhotra, R.S., Halila, M.H., Knights, E.J. and Verma, M.M. (1993) Current Status and Future Strategy in Breeding Chickpea for Resistance to Biotic and Abiotic Stresses. Euphytica, 73, 137-149. http://dx.doi.org/10.1007/BF00027190

[8] Gaur, P.M., Krishnamurthy, L. and Kashiwagi, J. (2008) Improving Drought-Avoidance Root Traits in Chickpea (Cicer arietinum L.)-Current Status of Research at ICRISAT. Plant Production Science, 11, 3-11. http://dx.doi.org/10.1626/pps.11.3 http://oar.icrisat.org/753/1/improve-lkrish.pdf

[9] Basu, P.S., Ali, M. and Chaturvedi, S.K. (2008) Terminal Heat Stress Adversely Affects Chickpea Productivity in Northern India-Strategies to Improve Thermo Tolerance in the Crop under Climate Change. http://www.isprs.org/proceedings/Xxxviii/8-W3/B3/B3-1-29.pdf

[10] Evans, C. and Etherington, J.R. (1990) The Effect of Soil Water Potential on Seed Germination of Some British Plants. New Phytologist, 115, 539-548. http://dx.doi.org/10.1111/j.1469-8137.1990.tb00482.x

[11] Covell, S., Ellis, R.H., Roberts, E.H. and Summerfield, R.J. (1986) The Influence of Temperature on Seed Germination Rate in Grain Legumes. I. A Comparison of Chickpea, Lentil, Soybean and Cowpea at Constant Temperatures. Journal of Experimental Botany, 37, 705-715. http://dx.doi.org/10.1093/jxb/37.5.705

[12] Ellis, R.H., Covell, S., Roberts, E.H. and Summerfield, R.J. (1986) The Influence of Temperature on Seed Germination Rate in Grain Legumes. II. Interspecific Variation in Chickpea (Cicer arietinum L.) at Constant Temperatures. Journal of Experimental Botany, 37, 1503-1515. http://dx.doi.org/10.1093/jxb/37.10.1503

[13] Garcia-Huidobro, J., Monteith, J.L. and Squire, G.R. (1982) Time, Temperature and Germination of Pearl Millet (Pennisetum typhoides S. \& H.): II. Alternating Temperature. Journal of Experimental Botany, 33, 297-302. http://dx.doi.org/10.1093/jxb/33.2.297

[14] Olivier, F.C. and Annandale, J.G. (1998) Thermal Time Requirements for the Development of Green Pea (Pisum sativum L.). Field Crops Research, 56, 301-307. http://dx.doi.org/10.1016/S0378-4290(97)00097-X

[15] Finch-Savage, W.E. (2004) The Use of Population-Based Threshold Models to Describe and Predict the Effects of Seedbed Environment on Germination and Seedling Emergence of Crops. In: Benech-Arnold, R.L., Sánchez, R.A., Eds., Handbook of Seed Physiology: Applications to Agriculture, Haworth Press, New York, 51-96.

[16] Angus, J.F., Cunningham, R.B., Moncure, M.W. and Mackenzie, D.H. (1981) Phasic Development in Field Crops. I. Thermal Response in the Seedling Phase. Field Crops Research, 3, 365-378. http://dx.doi.org/10.1016/0378-4290(80)90042-8

[17] Vaughton, G. and Ramsey, M. (2001) Relationships between Seed Mass, Seed Nutrients, and Seedling Growth in Banksia cunninghamii (Proteaceae). International Journal of Plant Science, 162, 599-606. http://dx.doi.org/10.1086/320133 
[18] Wang, R., Bai, Y. and Tanino, K. (2004) Effect of Seed Size and Sub-Zero Imbibitions Temperature on the Thermal Time Model of Winterfrat (Eurotia lanata (Pursh) Moq.). Environmental and Experimental Botany, 51, 183-197. http://dx.doi.org/10.1016/j.envexpbot.2003.10.001

[19] Mozafar, A. and Goodwin, J.R. (1986) Salt Tolerance of Two Differently Drought-Tolerant Wheat Genotypes during Germination and Early Seedling Growth. Plant and Soil, 96, 303-361. http://dx.doi.org/10.1007/BF02375135

[20] Hubert, J.J. and Shock, J.P. (1984) Probit: An Interactive Program in BASIC for Probit Analysis. Statistical Series No. 1984-160, University of Guelph, Guelph.

[21] Finney, D.J. (1971) Probit Analysis. Cambridge University Press, Cambridge, 333 p.

[22] Bradford, K.J. (1995) Water Relations in Seed Germination. In: Kigel, J. and Galili, G, Eds., Seed Development and Germination, Marcel Dekker, Inc, New York, 351-396.

[23] Ellis, R.H, Simon, G. and Covell, S. (1987) The Influence of Temperature on Seed Germination Rate in Grain Legumes. Journal of Experimental Botany, 38, 1033-1043. http://dx.doi.org/10.1093/jxb/38.6.1033

[24] Steinmaus, S.J., Prather, T.S. and Holt, J.S. (2000) Estimation of Base Temperatures for Nine Weed Species. Journal of Experimental Botany, 51, 275-286. http://dx.doi.org/10.1093/jexbot/51.343.275

[25] Probert, R.J. (2000) The Role of Temperature in the Regulation of Seed Dormancy and Germination. In: Fenner, M., Ed., Seeds: The Ecology of Regeneration in Plant Communities, 2nd Edition, CAB International, Wallingford, 261-292. http://dx.doi.org/10.1079/9780851994321.0261

[26] Labouriau, L.G. and Osborn, J.H. (1984) Temperature Dependence of the Germination of Tomato Seeds. Journal of Thermal Biology, 9, 285-294. http://dx.doi.org/10.1016/0306-4565(84)90010-X

[27] Alvarado, V. and Bradford, K.J. (2002) A Hydrothermal Time Model Explains the Cardinal Temperatures for Seed Germination. Plant, Cell and Environment, 25, 1061-1069. http://dx.doi.org/10.1046/j.1365-3040.2002.00894.x

[28] Cheng, Z. and Bradford, K.J. (1999) Hydrothermal Time Analysis of Tomato Seed Germination Responses to Priming Treatments. Journal of Experimental Botany, 50, 89-99. http://dx.doi.org/10.1093/jxb/50.330.89

[29] Ellis, R.H. and Barrett, S. (1994) Alternating Temperatures and Rate of Seed Germination in Lentil. Annals of Botany, 74, 519-524. http://dx.doi.org/10.1006/anbo.1994.1149

[30] Meyer, S.E., Debaene-Gill, S.B. and Allen, P.S. (2000) Using Hydrothermal Time Concepts to Model Seed Germination Response to Temperature, Dormancy Loss and Priming Effects in Elymus elymoides. Seed Science Research, 10, 213-223. http://dx.doi.org/10.1017/S0960258500000246 